\title{
Environmental Crimes: A Summary Of Enforcement Actions To Support Business Productivity
}

Rolando Pena-Sanchez, Texas A\&M International University, USA

\begin{abstract}
This study summarizes and compares the most relevant criminal enforcement actions to support business productivity conducted by the Environmental Protection Agency (EPA) during the fiscal years 1995-2008; the important actions under consideration are the environmental crime cases initiated, defendants charged, years sentenced, fines (and restitution) and pollutants' reductions. A correlation analysis was used to evaluate the significant relationship ( $p$-value $=0.002$ ) between the environmental crime cases initiated and the period of time in years; a power regression model (via curve fitting) was estimated to explain this relationship $\left(R_{\text {adj }}^{2}=0.998\right)$; the ratio of charged defendants to cases initiated (\%) was measured as an indicator of the yearly enforcement productivity undertaken by the EPA, whose $95 \%$ prediction interval is graphically presented. In addition, other density measures of enforcement actions against environmental crimes, such as the years sentenced per defendant, and the economic amount of fines and restitution per defendant are included.
\end{abstract}

Keywords: Environmental crimes; enforcement actions; business productivity; and statistical analysis

\section{INTRODUCTION}

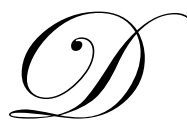

on't mess with Texas is a famous slogan used around the state of the lonely star to stop littering, which is considered as an environmental crime. An environmental crime is a felony against environmental legislation that is liable for prosecution (Roberts, 2009). Examples are: pollutant emissions to air, water and soil; trade in endangered species; improper disposal of wastes, etc. According to the EPA, a Criminal Enforcement Program focuses investigative resources on cases that involve negligent, knowing or willful violations of federal environmental law. Environmental crimes are the most difficult crimes to investigate because they require high levels of education in various topics, such as biology, chemistry, physics and the environment (Sasseville, 1997). Ever since the Environmental Protection Agency's Office of Criminal Enforcement was founded in 1982, there has been a steady increase in prosecuted environmental crimes.

Usually the violations are those that are deliberate and not the product of accidents or mistakes. Knowledge of the specific statutes or set of laws that prohibit the wrongful conduct is not required. When a violator is aware that the wrongful conduct is prohibited by law, the violation is said to be willful. If this does not describe what a person is reporting, it may be a case for a civil enforcement action. Frequently, the investigation of environmental crimes will uncover other crimes, such as lying to the government, fraud and/or conspiracy.

The following table outlines several cases related to the issue of sea water pollution and how it affects the industrial competitiveness, the trade and business productivity, and the reserves and resources in question. In some of these cases the industry affected by the pollution (Voorhees, 1997) is also the industry which caused the contamination. For example, the Shetland pollution, the Exxon Valdez accident and the most resent disaster of the British Petroleum (BP) company at the Gulf of Mexico were caused by accidental oil spills. Thus, the pollution has been inhibiting trade and business productivity for the oil industry in both situations: due to export bans and/or due to court judgment against the industry, see on Figure 3 the location of the EPA's Office of Wetlands, Oceans, and Watersheds. 
Table 1. Examples of Environmental Marine Disasters

\begin{tabular}{|l|c|c|c|}
\hline \multicolumn{1}{|c|}{ Case } & Industry Affected & $\begin{array}{c}\text { Trade \& Business } \\
\text { Productivity Effect }\end{array}$ & $\begin{array}{c}\text { Reserves \& } \\
\text { Resources Effect }\end{array}$ \\
\hline $\begin{array}{l}\text { British Petroleum Oil Spill at } \\
\text { Gulf of Mexico }\end{array}$ & Oil/Gas & Direct & High \\
\hline Sellafield Nuclear Plant & Nuclear Products & Direct & High \\
\hline The Oresund Crossing Issue & Transport and Food & Indirect & High \\
\hline Minamata Accident & Plastics & Indirect & High \\
\hline Black Sea Pollution & Tourism & Indirect & Migh \\
\hline Exxon Valdez Oil Spill & Oil/Gas & Direct & Medium \\
\hline Hong Kong Waste & Waste & Direct & Medium \\
\hline Baltic Sea Pollution & Food & Direct & Medium \\
\hline Mediterranean Sea Pollution & Tourism & Indirect & Low \\
\hline Shetland Oil Spill & Oil/Gas \& Food & Direct & Low \\
\hline Khain Sea Waste & Waste & Direct & \\
\hline
\end{tabular}

Source: http://www1.american.edu/projects/mandala/TED/projects/tedcross/xseap17.htm

As an example about how the violations to the environmental regulations (Watson, 2004) affects the business productivity beyond the border, we can review the next table, which contains cases of some environmental crimes' fines assigned by the Environmental Mexican Authorities to some of their assembly-for-export companies (maquilas) located at US-Mexico border; Table 2 specifies "why" the fine was assigned, as well as its corresponding year. According to the source, only $19.5 \%$ of the interviewed company's representatives were willing to collaborate with this critical information; where, most of the fine's cases are related to a wrong or bad waste-management.

Table 2. If your company received a fine, when and why?

\begin{tabular}{|c|l|}
\hline $\begin{array}{c}\text { When the fine } \\
\text { occurred? } \\
\text { What year?) }\end{array}$ & \multicolumn{1}{|c|}{ Why the fine occurred? } \\
\hline 1996 & Because the storage-room for dangerous waste had not written its legend at its entrance \\
\hline 1998 & We had initiated a process and we had not manifested before to the environmental authority a dangerous waste \\
\hline 2000 & Due to the bad disposal of filters and industrial water. Shortage of water was reported \\
\hline 2001 & By not giving a declaration of textiles-waste mixed with oil \\
\hline 2001 & Due to the lack of identification of some dangerous wastes \\
\hline 2001 & By burning trash, which had been producing air pollution \\
\hline 2002 & By not giving a declaration of a dangerous waste \\
\hline 2007 & $\begin{array}{l}\text { Wrong disposal and bad management of oils and dangerous wastes, which has been producing a contamination } \\
\text { into soil and underground water }\end{array}$ \\
\hline
\end{tabular}

Source: Pena-Sanchez, R. (2009).

Table 3. The EPA's statutes for the enforcement of federal environmental regulations

\begin{tabular}{|c|l|l|}
\hline Section & \multicolumn{1}{|c|}{ Statute } & \multicolumn{1}{|c|}{ Issue } \\
\hline III & Clean Water Act or "CWA" & Federal Water Pollution Control \\
\hline IV & The Resource Conservation and Recovery Act ("RCRA") & Federal Solid Waste Disposal Act ("SWDA") \\
\hline V & Clean Air Act ("CAA") & $\begin{array}{l}\text { Imposes penalties on violators of federal and state air } \\
\text { pollution control laws and regulations }\end{array}$ \\
\hline VI & The Toxic Substances Control Act ("TSCA") & $\begin{array}{l}\text { Governs the manufacture, processing, and distribution or } \\
\text { disposal of chemicals that pose danger to the public or } \\
\text { environment }\end{array}$ \\
\hline VII & $\begin{array}{l}\text { The Federal Insecticide, Fungicide, and Rodenticide Act } \\
\text { ("FIFRA") }\end{array}$ & $\begin{array}{l}\text { Regulates the manufacture, registration, transportation, } \\
\text { sale, and use of toxic pesticides }\end{array}$ \\
\hline VIII & $\begin{array}{l}\text { The examination of hazardous substances, considering the } \\
\text { Comprehensive Environmental Response, } \\
\text { Compensation, and Liability Act ("CERCLA") }\end{array}$ & $\begin{array}{l}\text { Authorizes the cleanup of hazardous substances at } \\
\text { contaminated sites and imposes criminal penalties on } \\
\text { those who violate its provisions }\end{array}$ \\
\hline IX & The Safe Drinking Water Act ("SDWA") & Federal Drinking Water Pollution Control \\
\hline X & $\begin{array}{l}\text { The Rivers and Harbors Act of 1899 ("RHA"), and the } \\
\text { Ocean Dumping Act of 1972 ("ODA") }\end{array}$ & $\begin{array}{l}\text { Together with the CWA, restores and protects the } \\
\text { quality of the nation's surface and ground waters }\end{array}$ \\
\hline X1 & The Endangered Species Act ("ESA") & Imposes penalties on crimes against wildlife \\
\hline
\end{tabular}

Source: Inman, Elaine K. (2001). 
Table 3 describes the EPA's statutes that govern the enforcement of federal environmental regulations through criminal prosecution.

\section{OBJECTIVE}

The research objective of this article is to compare and evaluate some of the main criminal enforcement actions conducted by the Environmental Protection Agency (EPA) during the fiscal years 1995-2008; the percentage ratio of charged defendants to cases initiated is presented as an index (Cooper, 2008) of the annual internal productivity undertaken by the EPA.

\section{DATA AND METHODOLOGY}

This study was carried out with a data set conformed from 14 annual reports located at an official government website (EPA, 2008), which is indicated in the References section:

http://cfpub.epa.gov/compliance/resources/reports/accomplishment/details.cf

As part of the methodology, the correlation coefficients (Cooper, 2008) for the involved variables (enforcement actions) were estimated; other density measures of enforcement actions against environmental crimes, such as the years sentenced per defendant, and the economic amount of fines and restitution per defendant were evaluated; In addition, a power regression model was estimated to explain the relationship between the environmental crime cases initiated and the period of time in years; the ratio of charged defendants to cases initiated (\%) was measured as an indicator of the yearly enforcement productivity undertaken by the EPA, whose $95 \%$ prediction interval (Berenson, 2009) is presented. The results of these statistical calculations are shown in the next section.

\section{RESULTS}

The following Table 4 contains descriptive statistics of criminal enforcement actions conducted by the EPA for the period 1995-2008, where:

Years sentenced per defendant $=$ Years Sentenced $/$ Defendants Charged

Ratio of charged defendants to cases initiated $(\%)=$ [Defendants Charged / Environmental crime cases initiated] (100)

Fines and restitution per defendant $(\$$ thousands $)=[$ Fines and restitution $(\$$ Millions $) /$ Defendants Charged $]\{1000\}$

Table 4. Descriptive statistics of the indicated enforcement action (1995-2008)

\begin{tabular}{|l|c|c|}
\hline \multicolumn{1}{|c|}{ Criminal enforcement action } & Mean & Standard deviation \\
\hline Environmental crime cases initiated & 492.21 & 51.53 \\
\hline Defendants Charged & 289.64 & 58.93 \\
\hline Years Sentenced & 146.06 & 63.84 \\
\hline Fines and restitution (\$ Millions) & 77.90 & 36.61 \\
\hline Pollutant reductions (millions of pounds) & 53.31 & 92.39 \\
\hline Years sentenced per defendant & 0.49 & 0.15 \\
\hline Ratio of charged defendants to cases initiated (\%) & 61.56 & 16.20 \\
\hline Fines and restitution per defendant ( \$ thousands) & 269.13 & 109.37 \\
\hline
\end{tabular}


Table 5. Correlation coefficients and their p-values of the Indicated enforcement action (1995-2008)

\begin{tabular}{|c|c|c|c|c|c|c|}
\hline & $\begin{array}{l}\text { Environmental } \\
\text { crime cases } \\
\text { initiated }\end{array}$ & $\begin{array}{c}\text { Defendants } \\
\text { charged }\end{array}$ & $\begin{array}{c}\text { Ratio of } \\
\text { charged } \\
\text { defendants to } \\
\text { cases initiated } \\
(\%)\end{array}$ & $\begin{array}{c}\text { Pollutant } \\
\text { reductions } \\
\text { (millions of } \\
\text { pounds) }\end{array}$ & $\begin{array}{c}\text { Years } \\
\text { sentenced } \\
\text { per } \\
\text { defendant }\end{array}$ & Year \\
\hline $\begin{array}{l}\text { Environmental crime } \\
\text { cases initiated }\end{array}$ & 1 & $\begin{array}{c}0.436 \\
\{0.119\}\end{array}$ & $\begin{array}{c}-\mathbf{- 0 . 6 7 5}^{* *} \\
\{0.008\}\end{array}$ & $\begin{array}{l}\mathbf{0 . 9 3 0}^{* *} \\
\{0.002\}\end{array}$ & $\begin{array}{c}0.419 \\
\{0.136\}\end{array}$ & $\begin{array}{r}-\mathbf{0 . 7 6 2}^{*} \\
\{0.002\}\end{array}$ \\
\hline Defendants charged & & 1 & $\begin{array}{c}0.341 \\
\{0.233\} \\
\end{array}$ & $\begin{array}{c}0.504 \\
\{0.248\} \\
\end{array}$ & $\begin{array}{r}\mathbf{0 . 5 8 0} \\
.\{0.030\} \\
\end{array}$ & $\begin{array}{c}-0.307 \\
\{0.285\} \\
\end{array}$ \\
\hline $\begin{array}{l}\text { Ratio of charged } \\
\text { defendants to cases } \\
\text { initiated }(\%)\end{array}$ & & & 1 & $\begin{array}{c}-0.526 \\
\{0.225\}\end{array}$ & $\begin{array}{c}0.087 \\
\{0.767\}\end{array}$ & $\begin{array}{l}\mathbf{0 . 5 5 9}^{*} \\
\{0.038\}\end{array}$ \\
\hline $\begin{array}{l}\text { Pollutant reductions } \\
\text { (millions of pounds) }\end{array}$ & & & & 1 & $\begin{array}{c}0.540 \\
\{0.210\}\end{array}$ & $\begin{array}{c}-0.694 \\
\{0.083\}\end{array}$ \\
\hline $\begin{array}{l}\text { Years sentenced per } \\
\text { defendant }\end{array}$ & & & & & 1 & $\begin{array}{c}-0.152 \\
\{0.603\}\end{array}$ \\
\hline Year & & & & & & 1 \\
\hline
\end{tabular}

**Correlation is significant at the 0.01 level (2-tailed); *Correlation is significant at the 0.05 level (2-tailed)

Table 5 presents the most significant correlations for the criminal enforcement actions; where only the upper triangle correlation matrix is shown; the non-significant correlations for other density measures of enforcement actions against environmental crimes are not included.

Table 6. Analysis of variance for the power regression model

\begin{tabular}{|l|c|c|c|c|c|}
\hline \multicolumn{1}{|c|}{ Source of Variation } & Sum of Squares & df & Mean Square & F test & p-value \\
\hline Regression & 531.977 & 1 & 531.977 & 6894.623 & 0.001 \\
\hline Residual & 1.003 & 13 & 0.077 & & \\
\hline Total & 532.980 & 14 & & & \\
\hline
\end{tabular}

Dependent variable: Environmental crime cases initiated (y); Independent variable: Time (years)

Table 7. Coefficient estimate of the power regression model

\begin{tabular}{|l|c|c|c|c|}
\hline \multirow{2}{*}{$=t_{\text {year }}^{\beta}$, for $1995 \leq t \leq 2008$} & $\boldsymbol{\beta}$ & Std. Error & $\mathbf{t}_{\text {test }}$ & p-value \\
\cline { 2 - 5 } & 0.811 & 0.010 & 83.034 & 0.001 \\
\hline
\end{tabular}

$\mathrm{R}_{\text {adj }}^{2}=0.998$; the equation was estimated without the constant term

In Figure 1, the curve shown near to the horizontal axis is the ratio of the two curves on top; this is according to definition mentioned before at the beginning of this section, where the measurements are presented in natural logarithmic scale.

During the examination of the linear trend exhibited by the curve "ratio", we decided to construct a $95 \%$ prediction interval (Berenson, 2009), which is shown in Figure 2; this graphic reveals a wave pattern with a longterm positive trend, and Table 8 confirms that at a significance level of $\alpha=0.05$, the slope $\left(\beta_{1}\right)$ of such trend has a significant magnitude ( $\mathrm{p}$-value $=0.038)$.

Table 8. Regression coefficients estimates of the linear trend ratio

\begin{tabular}{|l|c|c|c|c|c|}
\hline \multirow{2}{*}{$\begin{array}{l}\text { Linear trend ratio }=\mathrm{b}_{0}+\mathrm{b}_{1} t, \\
\text { for } 1995 \leq t \leq 2008\end{array}$} & $\beta$ & Estimate & Std. Error & $\mathrm{t}_{\text {test }}$ & $\mathrm{p}$-value \\
\cline { 2 - 6 } & $\beta_{0}$ & -4270.26 & 1855.83 & -2.301 & 0.040 \\
\cline { 2 - 7 }
\end{tabular}

Dependent Variable: Ratio of charged defendants to cases initiated (\%); Independent Variable: Year (t) 
Figure 1. Sequence plot for the indicated enforcement action

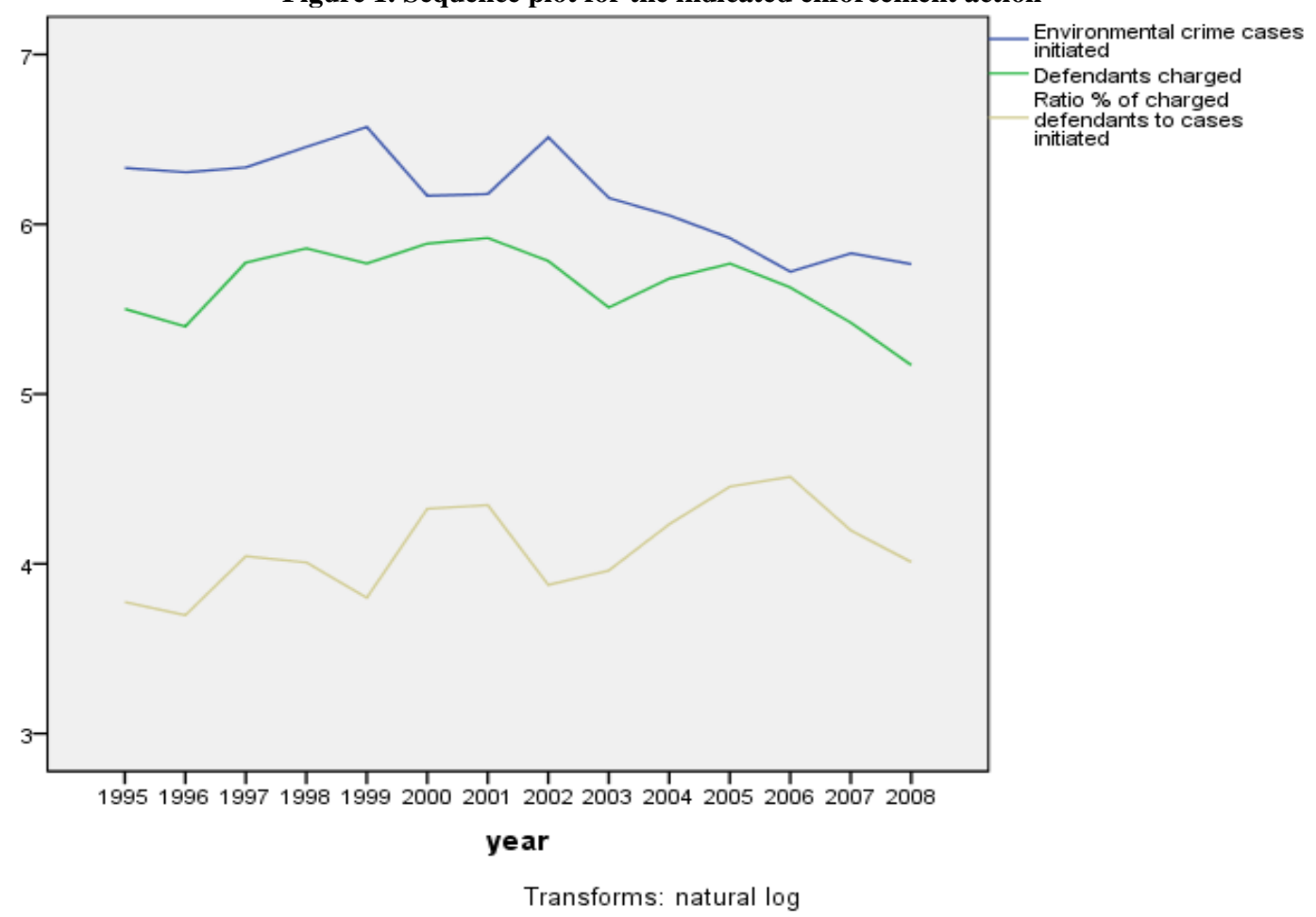

Figure 2. The $95 \%$ prediction interval for the ratio of charged defendants to cases initiated (\%)

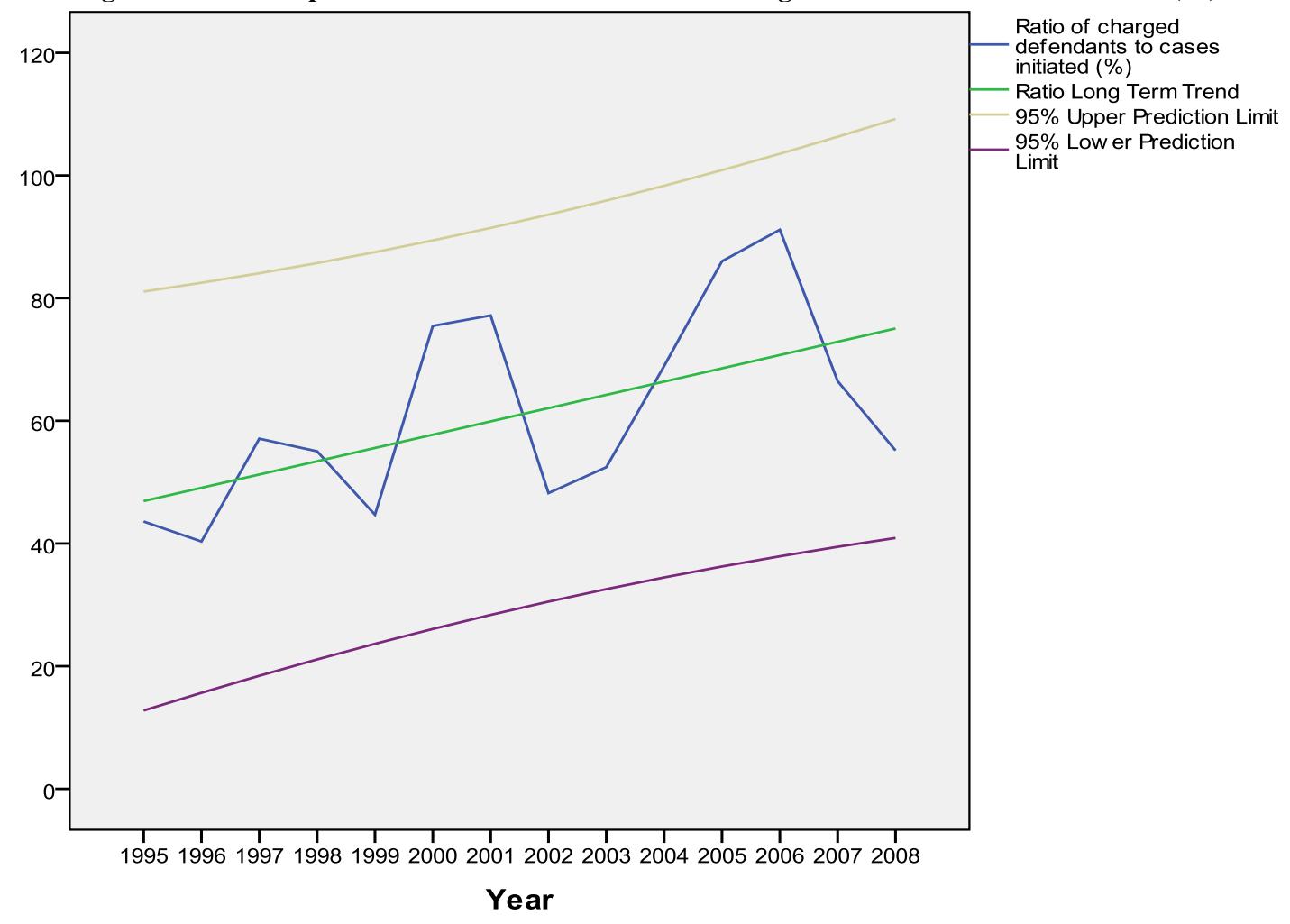


Figure 3. EPA-Office of Water (OW) Organizational Chart (September 21, 2010)

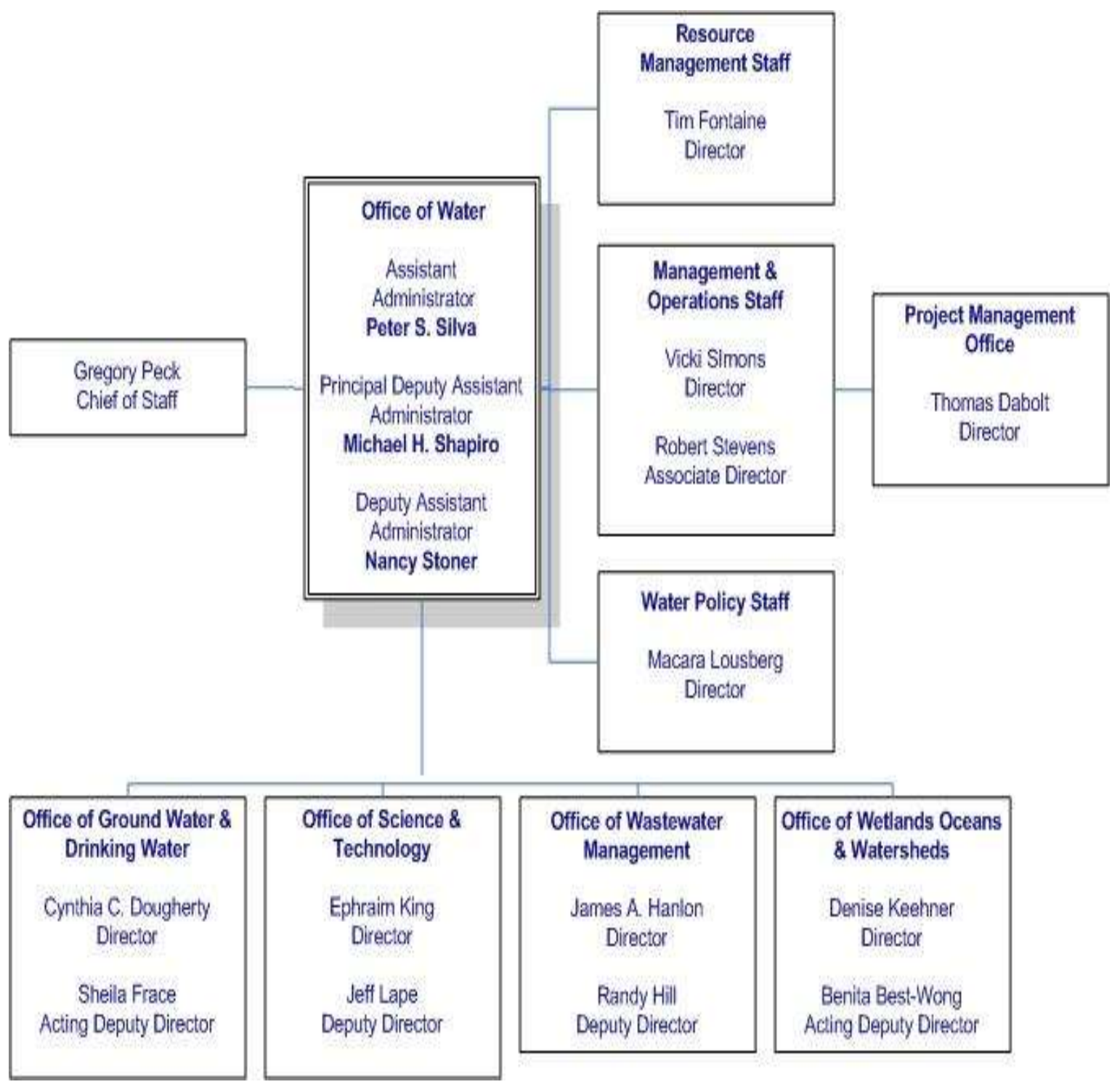

Source: http://water.epa.gov/aboutow/org/orgchart/index.cfm

\section{DISCUSSION}

Table 3 and as well as Figure 3 confirm that from a theoretical point of view: The EPA has a very strong legal and technical structure to proceed against the industries and individuals responsible of environmental crimes.

For example, "a federal jury on May 8, 2009 acquitted a Columbia, Md.-based chemical and building material company and three of its former executives on conspiracy charges and Clean Air Act violations relating to a vermiculite mine that Grace operated in Libby, Mont., from 1963 to 1990. The government charged that the company and its executives conspired for 26 years to knowingly release asbestos-laced vermiculite and then hid the health hazards from miners, residents and the government. The asbestos is blamed for causing about 2,000 illnesses and 225 deaths in and around Libby (Roberts, 2009). Legal experts say environmental enforcement is a top priority of the Obama administration and companies should expect more enforcement activity, especially as it relates to the 
Clean Air Act, the Clean Water Act and the Resource Conservation and Recovery Act. As such, now is not the time for companies to be complacent about their environmental oversight and compliance activities, they warn".

Source: http://www.nytimes.com/2009/05/09/us/09grace.html

The authorities at the Environmental Protection Agency (EPA) dealing with water issues have been organized according to Figure 3: Office of Water (OW) Organizational Chart.

\section{CONCLUSIONS}

Analytical (Table 7) and pictorial evidence (Figure 1) indicate the same: At the significance level of $\alpha=0.01$, there is a significant power pattern on time (in years) of the environmental crime cases initiated for the period 1995-2008. The graph of Figure 1 shows that the number of crime cases initiated by the EPA is decreasing on time; on the other hand, the defendant charges are decreasing more slowly; moreover, the ratio of charged defendants to the cases initiated shows an undulated performance with a growing tendency inside of their prediction limits.

Figure 2 confirms that the enforcement actions undertaken by the EPA to support business productivity have been showing a significant positive long term trend; this should be a motivation for the EPA's authorities to continue with their efforts to reduce the density and risk (Crawford-Brown, 1999) of all type of factors associated to environmental crimes.

For the complex question: How to prevent the environmental crimes? A strong legal and technically standardized system administrated by the EPA is just the starting point. It's probably true that, the humans are willing to make an evolutionary change until they're facing the precipice of their extinction; in other words: the humans learn until the edge of the abyss of their extinction is very near; which is a statement of catastrophic proportions mentioned in a science fiction movie "The Day the Earth Stood Still" (2008), where an alien called Klaatu (starring Keanu Reeves) travels across the universe to warn of an impending global environmental crisis.

In general, we can conclude that an environmental crime represents just the tip of the iceberg; thus, each approach (enforcement action) to prevent an environmental crime is a challenge to put in action the iceberg principle, or the iceberg theory of change: Only small proportions of many things are clearly evident.

\section{AUTHOR INFORMATION}

Rolando Pena-Sanchez is an Associate Professor of Decision Sciences in the Division of International Business and Technology Studies at Texas A\&M International University. He received his Ph.D. from Rice University, USA in 1990. His research interests include: Multivariate and nonparametric statistical methods applied to business administration and environmental risk management. His more recent research has appeared in the College Teaching Methods \& Styles Journal, the International Journal of Innovation and Learning, the Journal of Border Educational Research, the Journal of Competitiveness Review, as well as in the International Business and Economics Research Journal.

\section{REFERENCES}

1. Berenson, M. L., Levine, D. M., Krehbiel, T. C. (2009). Basic Business Statistics: Concepts and Applications. 11th Edition. Pearson-Prentice-Hall.

2. Crawford-Brown, Douglas J. (1999). Risk-Based Environmental Decisions: Methods and Culture; Kluwer Academic Publishers.

3. Cooper, D.R. and Schindler, P. S. (2008). Business Research Methods, $10^{\text {th }}$ Ed. McGraw-Hill.

4. EPA (2008). Data, Planning and Results; Accomplishment Reports FY 1995, 1996, ..., 2008. Source: http://cfpub.epa.gov/compliance/resources/reports/accomplishment/details.cf

5. Inman, Elaine K. (2001). Environmental crimes; The American Criminal Law Review. Source: http://www.allbusiness.com/government/environmental-regulations/1119978-1.html 
6. Pena-Sanchez, R. (2009). Employee Perceptions of the Environmental Risk: Maquila Industries on the Mexico-U.S. Border. Intl. Business and Economics Research Journal. Vol. 8, Number 1, pp 51-58.

7. Roberts, S. (2009). Experts predict uptick in pollution prosecutions. Business Insurance, 43(20)

8. Sasseville, D. R., Wilson, W. G. and. Lawson R. W (1997). ISO 14000 Answer Book: Environmental Management for the World Market. John Wiley \& Sons, Inc.

9. Voorhees, J. and Woellner, R.A (1997). International Environmental Risk Management: ISO 14000 and the Systems Approach; Lewis Publishers.

10. Watson, R. P., Kiel, D. C., and Robar, S. F. (2004). Managing Environmental Policy: A Casebook; Krieger Publishing Co.

\section{NOTES}

